\author{
Zdzisław Mikulski
}

\title{
THE DEVELOPMENT OF THE UTILISATION OF WATER POWER IN POLAND
}

\begin{abstract}
First hydroelectric power stations in Poland were built in 19th century, mostly in the region of Podhale (Carpathian tributaries of the Vistula River) and in the Old Polish Industrial District (for the needs of the iron and steel industry) from the initiative of Stanisław Staszic. They were used in mills and saw mills, for home lighting in settlements, etc. After World War I two medium size hydroelectric power stations were constructed in Pomerania (Gródek and Żar) and the construction of a dam (at that time the largest in Europe) was started in Rożnów on the Dunajec River (50 MW); the hydroelectric power station was opened as late as 1941. A small growth in this field took place in the 1950s and 1960s, and in the late 1960s / early 1970s large hydroelectric power stations were built (Solina, Włocławek, Żydowo). The largest growth occurred in the late 1980s and early 1990s, when the two giant peak-load, pumped-storage power stations were put into operation (Porabka-Żar: $500 \mathrm{MW}$ and Żarnowiec: $680 \mathrm{MW}$ ), reaching the total power of $2000 \mathrm{MW}$. The most recent two large installations are: Czorsztyn-Niedzica (92 MW, 1997) and the modernisation of Solina (200 MW, 2003).
\end{abstract}

Key words: hydro power, hydroelectric power stations, water power industry, water power engineering history of technology, Poland.

The development of the water power utilisation in Poland can be divided into several phases. First hydroelectric power stations were built already at the end of the $19^{\text {th }}$ century, but until the beginning of the $20^{\text {th }}$ century small power plants of local significance dominated. They were particularly common in the region of Podhale (Jost, 1998) and entire water energy schemes had been built in the Old Polish Industrial District (Staropolski Okręg Przemysłowy) during the times of the Kingdom of Poland, from the initiative of Stanisław Staszic (1755-1826). A pronounced development didn't come, though, until the invention of the water turbine by Francis in 1849 (Spoz, 1998). It was also in the late $19^{\text {th }}$ century that attention was turned to the Carpathians and Sudetes, as regions favourable for the construction of large reservoirs and where it was possible to use greater heads for the production of hydro-electric power. Such projects were initiated by the Lwów Polytechnic (Szkoła Politechniczna) in the early 20th century. Investigations of the hydro power of more important Carpathian rivers were started by Karol Pomianowski (1874-1948), member of the Chair of Water Engineering. As a result of this research a 4-volume work Sity wodne w Galicji (Hydro Power in Galicia - "Galicia" was the name of the Austrian sector of the partitioned 
Poland) was written under his direction in 1905-1908; it was the first publication in Poland dealing with the cadastre of hydro power in Poland. At the same time at the Polytechnic Society (Towarzystwo Politechniczne) in Lwów a commission dealing with the utilisation of water power was created, and in 1906 the investigation of water power became a responsibility of the hydrographical service; in 1907 a decree regarding the construction of water reservoirs on selected Carpathian rivers (Soła, Skawa, Dunajec, Stryj, Opór) was issued. In 1911 Gabriel Narutowicz (1865-1922) visited Galicia to familiarise himself with the hydrotechnical concepts applied there (Mikulski, 2003).

At the turn of the $20^{\text {th }}$ century in the Prussian sector of the partitioned Poland an intensive development scheme of building hydro-electric power stations on the rivers of Western Pomerania was started. Hydro-electric power stations Kamienna on the Drawa River and Struga on the Słupia River (0.25 MW of power each) were constructed. In 1900 and 1904 two relatively small power plants on the Reda River (Płoty: 0.13 MW and Prusinowo: $0.08 \mathrm{MW}$ ) were built, and already in 1905, the first power plant on the Nysa Łużycka River, a tributary of the Odra River (Zieliska: 1.13 MW). Altogether, in the years 1898-1906 five hydro-electic power plants were operational, producing 2.1 MW of total power. From 1907 until the break-out of the World War I in 1914, a total of 22 hydro-electric power stations were built producing 26.9 MW of total power, of which seven were located on the left-bank tributaries of the Odra (including the largest station Pilchowice on the Bóbr River, producing 7.5 MW of power).

The Polish hydrological service contributed significantly to the research on water power resources. The Department of Hydrography of the Ministry of Public Works, created in March 1919 was the first organisational unit of the hydrological service. In July 1921 a decree (signed by Gabriel Narutowicz) was issued dealing with the organisation of the hydrographical service; a.o., the decree brought into being the Department of Water Research, transformed in 1923 into the Division of Water Power Research and directed by Henryk Herbich (1896-1968). After several years of research the first volumes of the series Cadastre of Water Powers were published: Dunajec in 1928 and San in 1929.

In 1923, at the suggestion of the State Council of Electricity a temporary committee, representing Poland at the first World Power Conference (WPC), was brought into being. In 1926 the Polish Energy Committee (PKEn), dealing with research on energy resources in Poland, including water power resources was founded. From the very beginning the Water Commission led by Mieczysław Rybczyński (1873-1937), Professor of the Technical University in Warsaw, was active within PKEn (Mikulski, 1995). The tasks of the Committee included clarifying and solving current energy issues in Poland, as well as issues of electrical, heat, gas, water and wind power industries. Projects and works dealing with energy sources, gas, oil, water power, peat and wood, brown coal and black coal, wind power and substitute fuels had 
been performed and published. Among these works was also the publication "Water Power in Poland" (1936) by M. Rybczyński. Representatives of PKEn participated in meetings of the International Executive Council and of the World Power Conference. After the war the organisation changed its name to Polish Committee of the World Power Conference (Kubiatowski, 1990).

During the first decade after World War I the number of hydro-electric power stations in Poland increased, in particular of those utilising the flood control reservoirs being built at that time. Thirty-eight cooperating hydroelectric power stations were built during that time (68 MW of total power), among them the first hydro-electric power stations in Pomerania on the Wda River (Czarna Woda): Gródek (3.9 MW, 1923) and Żur (8.0 MW, 1929), designed by the outstanding Polish hydro power engineer Alfons Hoffmann (1885-1963).

The years 1930s were marked by a large increase of power (99.5 MW), due to the construction of larger hydro power stations in Lower Silesia and Pomerania, and in particular of a large plant in Dychów on the lower Bóbr River in 1936 (79.5 MW). Two large navigation reservoirs were built on the tributaries of the Odra River: Otmuchów on the Nysa Kłodzka River in 1933 (4.8 MW) and Turawa on the Mała Panew River in 1937 (1.8 MW). (The latter was finished as late as 1948.) Within the contemporary borders of Poland the construction of a large dam (without a hydro-electric power station) in Porabka in the Sola River was finished and the construction of a dam and a hydro-electric power station in Rożnów on the Dunajec River, together with a compensation reservoir and a hydro-electric power station in Czchów below Rożnów, was significantly advanced. At that time, Rożnów was the largest power plant of this kind in Europe. In 1936 the largest scientific work in Poland, entitled Zasady wyzyskiwania sit wodnych, pomiary i obliczenia wodne (Principles of Utilisation of Water Power, Measurements and Water Calculations - Lwów 1936) written by Maksymilian Matakiewicz (1875 -1940) and Michał Mazur (1891-1952) from the Lwów Technical University (Politechnika Lwowska) was published; it was the last, seventh part of the well known series Water Engineering, whose publication was started in 1894 by Józef Rychter $(1843-1917)$. For the $20^{\text {th }}$ anniversary of Poland's independence H. Herbich completed Zagadnienie sit wodnych (The Issue of Water Power 1938), in which he described the state of water power resources in Poland in individual energy regions and the 30-years long programme of research on water power station construction in Poland.

During the World War II and the first post-war years, the construction of the dam and the hydro-electric power station in Rożnów was completed (50 MW, 1941), under the direction of Wacław Balcerski (1904-1972) and in 1949 a similar compensation complex was completed in Czchów below Rożnów (8.0 MW). The construction of the reservoir in Turawa and of others, damaged during the military actions, was also completed. As late as in 1950s the plant in Dychów (79.5 MW) was rebuilt and activated; it was the largest power station on the lower Bóbr River - the first peak-flow supplementary 
pumped-storage hydro-electric power station (Spoz, 1998). Already in 1951 a project of energy-orientated utilisation of the flood control reservoir, built in 1936, in Porabka on the Sola River was prepared and the construction of a 12.6 MW hydro-electric power station was started. The station began operating in 1953.

In 1952, the Committee for Water Management was founded at the presidium of the Polish Academy of Sciences (PAN); one of its tasks was the preparation of the "Long-term Water Management Plan for Poland". The issue of the cadastre of water power in Poland was taken up again and already in 1953 a publication on the station Kamienna was issued. The Energy Team of the Committee for Water Management of PAN, in turn, led by Kazimierz Kopecki (1904-1984) from Gdańsk Technical University, prepared materials necessary for the further utilisation of water power in Poland, in particular materials regarding: the state of water power stations in Poland, hydrological foundations of water power engineering, plans of its development, mechanical and electrical equipment of water power stations and small water power stations. The 2-volume Zarys planu perspektywicznego gospodarki wodnej $w$ Polsce (Outline of Long-term Water Management Plan for Poland), published in 1959, included, in Volume II, Chapter 6 "Water power engineering", consisting of five sections: 1 . Development of water power engineering; 2. Hypothesis of the development of power engineering in Poland; 3. Cadastre of water power; 4. Economic justification of water power engineering; 5. Suggested localisation of water power schemes in Poland.

Theoretical water power resources of rivers in Poland, calculated by Alfons Hoffmann, Professor of Gdańsk Technical University, were equal on the average to $2625 \mathrm{MW}$ of power and $23000 \mathrm{GWh}$ of energy. The following rivers have the largest power: the lower Vistula (676 MW), the middle Vistula (340 MW), the Odra (246 MW), the Dunajec (176 MW), the San (148 MW) and the Warta (133 MW). Also, first lecture notes and college textbooks have been published.

The late 1950s and early 1960s were a period of boom in the water power utilisation of rivers in Poland: numerous new power plants were being built. In 1958 a 9.8 MW power station was built on the Odra in Brzeg Dolny, taking advantage of the necessity of the creation of the subsequent weirs. Already in 1960 one of the largest lowland reservoirs was created on the Brda River in Koronowo, with a large power station nearby (26.0 MW) and two years later (1962), a compensation reservoir Tryszczyn with a 3.3 MW power station. In the power station scheme of the upper San River the first power station, Myczkowce, was built (8.3 MW) near a compensation reservoir for the future large reservoir in Solina. Finally in 1963, a large power station in Dębe on the lower Narew River (20.0 MW) was constructed, near the dam forming Lake Zegrzyńskie near Warsaw in the vicinity of the confluence of its tributary Bug with the Narew River.

The late 1960s were the period of the great peak-load, pumped-storage power stations in Poland. The construction in 1967 of the dam in Tresna 
above Porabka with a 21.0 MW power station next to it was the first step in the creation of the Sola River cascade. In 1968 the dam in Solina on the San River was put into operation; it created the largest retention reservoir in Poland (472 million $\mathrm{m}^{3}$ ). The peak-load, pumped-storage power station installed next to the dam reached $136 \mathrm{MW}$ of power. Finally in 1970 the only weir on the lower Vistula in Włocławek was opened, with a 160 MW run-ofriver station with limited storage. In the same year, the first and only pumped-storage power station in Poland utilising two lakes (Lake Kamienne and Lake Kwiecko) with the difference of levels equal to $80 \mathrm{~m}$ and $151 \mathrm{MW}$ of power, was built in Żydowo in Western Pomerania. This great interest in water power engineering was conducive for publishing new books in this field (Łaski, 1971; Michałowski, Plutecki, 1975; and others).

The turn of the 1980s is marked by the creation of two giant hydro-electric power stations: Porabka-Żar (500 MW) in 1979 and Żarnowiec on Lake Żarnowieckie (680 MW). In the former, waters of the retention reservoir in Porabka and of the reservoir created on the top of Mount Żar (at the elevation of $440 \mathrm{~m}$ ) were utilised, creating a plant of European class, and even of the world-class (Spoz, 1998). The latter power plant is a pumped-storage power station with an upper artificial reservoir, with the difference of elevation of the two reservoirs equal to $120 \mathrm{~m}$. Equipping the power station in generating sets with $170 \mathrm{MW}$ of power each for each head equal to $120 \mathrm{~m}$ makes this object unique on the world scale with respect to size of mechanical components and the the discharge of the turbines (Spoz, 1998). The utilisation of hydro power of rivers in Poland reached 2000 MW. It wasn't until 1997 that the last of the large hydro-electric power stations (a peak-load, pumped-storage one), Czorsztyn-Niedzica on the Dunajec River, was put into operation; together with a power station on the compensation stage Sromowce Wyżnie, put into operation in 1994, it reached $92 \mathrm{MW}$ of power. At the end or the $20^{\text {th }}$ century, in 128 cooperating hydro-electric power stations the power of around $2200 \mathrm{MW}$ was achieved, that is, $6.5 \%$ of the power installed in the whole power system in Poland (Kułagowski, 2001). Finally in autumn 2003 the modernisation of the power station Solina on the San was completed, increasing its power to $200 \mathrm{MW}$.

Low-capacity water power stations $(<5 \mathrm{MW})$, utilised in agriculture and by local small businesses, and included in the general network only to a small degree, constitute a separate issue. They were created during the partitions of Poland and between the two World Wars and were destroyed to a large extent during World War II and soon afterwards. Low-capacity hydro power industry, however, forms around $15 \%$ of the hydro power resources of our country and, according to the data from 1950s, consisted of about 5000 power plants. A new decree of the Council of Ministers ( $\mathrm{Nr} 192 / 81)$ regarding the development of low-capacity water power industry (MEW) led to the working out of the "Field study of low-capacity hydro-electric power stations a programme of the creation of low-capacity water power industry through the year 2000" (Energoproject). As the result of research an instruction of 


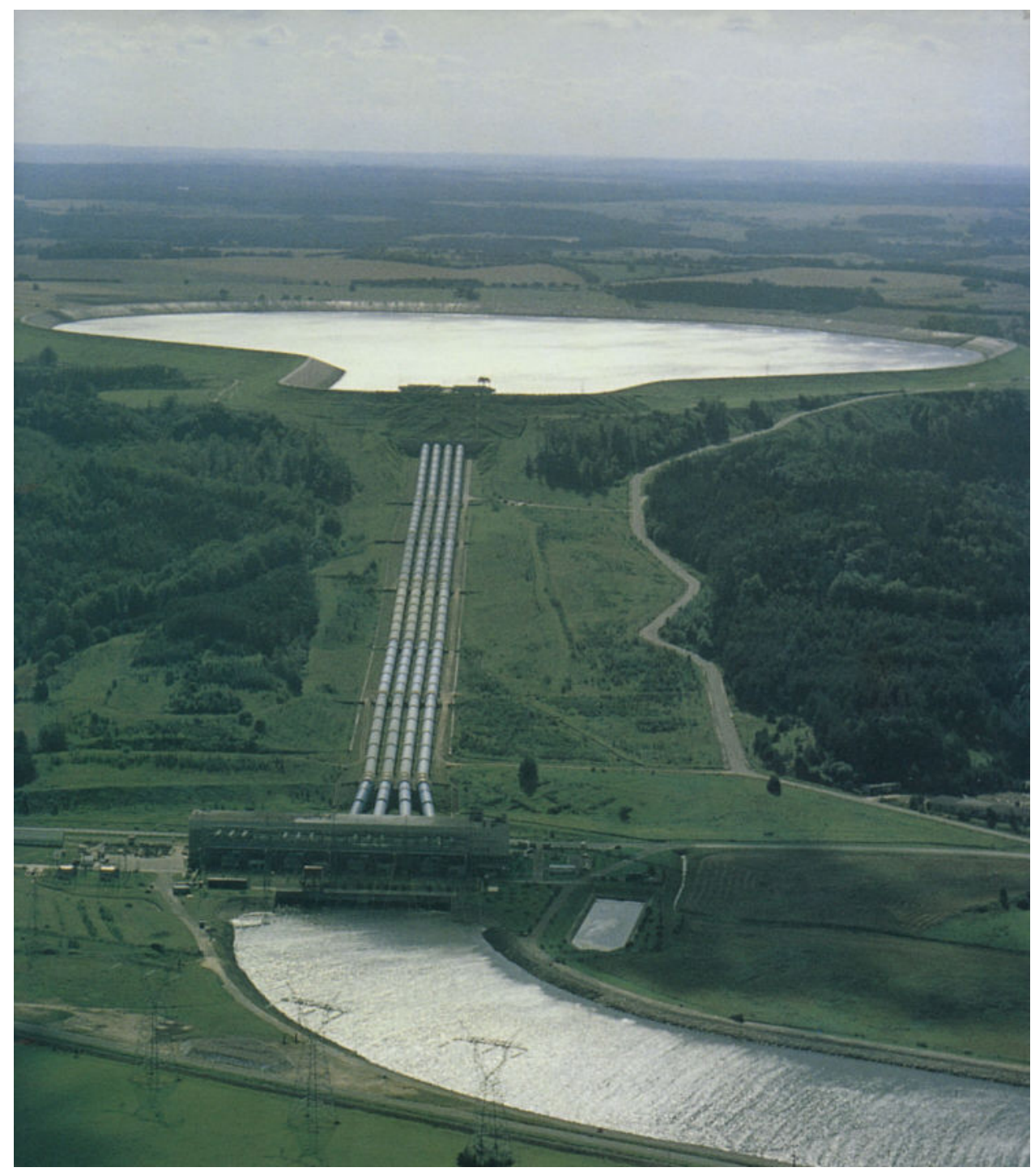

Photo 1. The largest peak-flow pumped-storage hydro power station in Poland: Żarnowiec on Lake Żarnowieckie. 


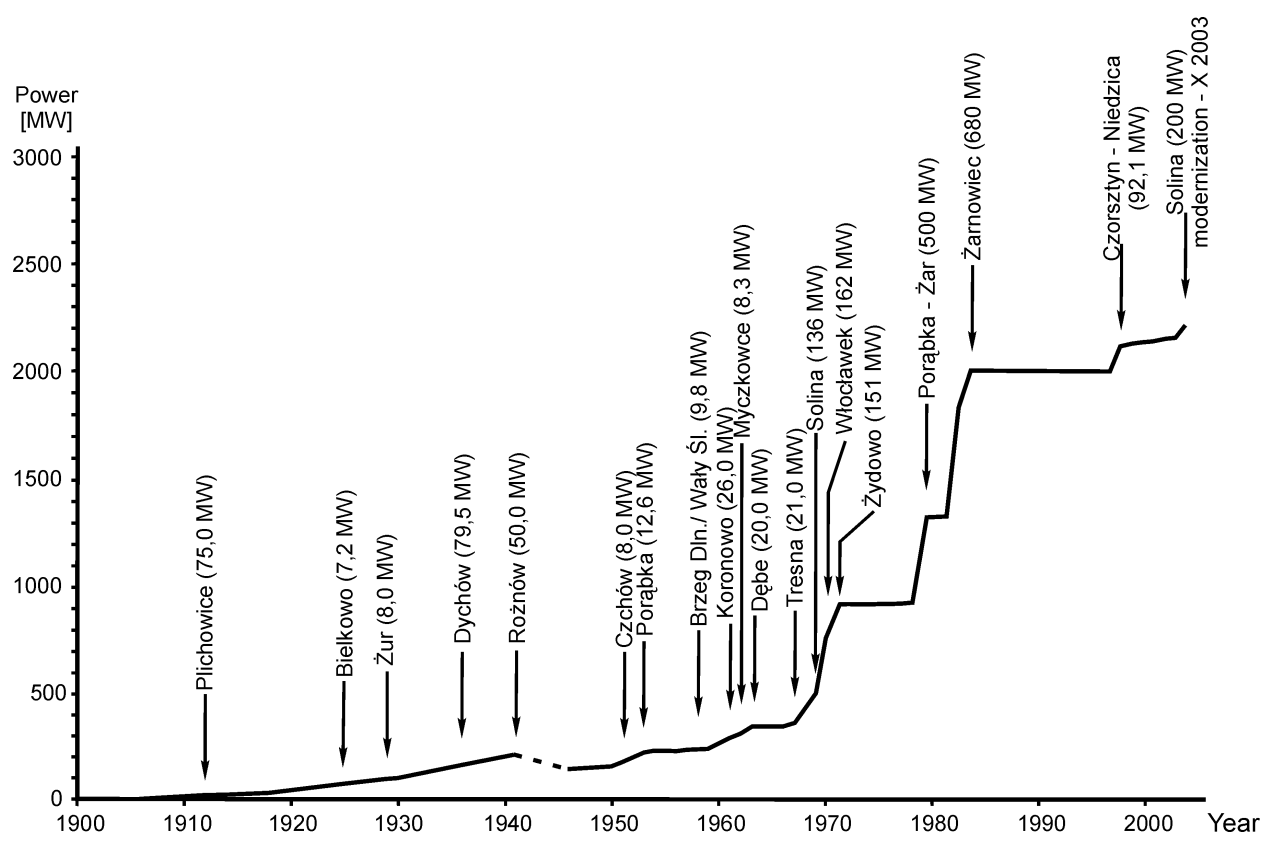

Fig. 1. Development of hydro-electric power stations in Poland.

exploitation of a low-capacity hydro-electric power station, geared towards owners of the plants, was published in 1987. In 1988, Marian Hoffmann initiated the founding of the Society for the Development of Low-capacity Hydro-electric Power Stations (TRMEW) and became its leader. Despite of many technical and economic difficulties, until the end of 1997, 266 small water power stations of total power $28 \mathrm{MW}$ were put into operation and attached to the distribution networks of the power stations in Poland (Spoz, 1998). The statistics for the end of the $20^{\text {th }}$ century show the existence of over 300 small hydro-electric power stations.

In 1991 the Society for Hydro-electric Power Stations (TEW) was founded, initiated by the employees of the largest hydro-electric power stations in Poland. The main goal of the Society is the protection and representation of the existing hydro power stations belongins to the professional water power industry and efficient promotion of the development of water power engineering and of other renewable energy sources. In 1988 the Society published a small monograph 100 lat energytyki wodnej na ziemiach polskich (100 Years of Water Power Industry in Poland), edited by a team led by Jerzy Spoz, the author of several publications dealing with water power engineering in Poland. Information included in this publication has been used in this paper.

In December 1993, as a result of the restructurisation of the water power industry a new company, "Peak-flow Pumped-storage Water Power Stations 


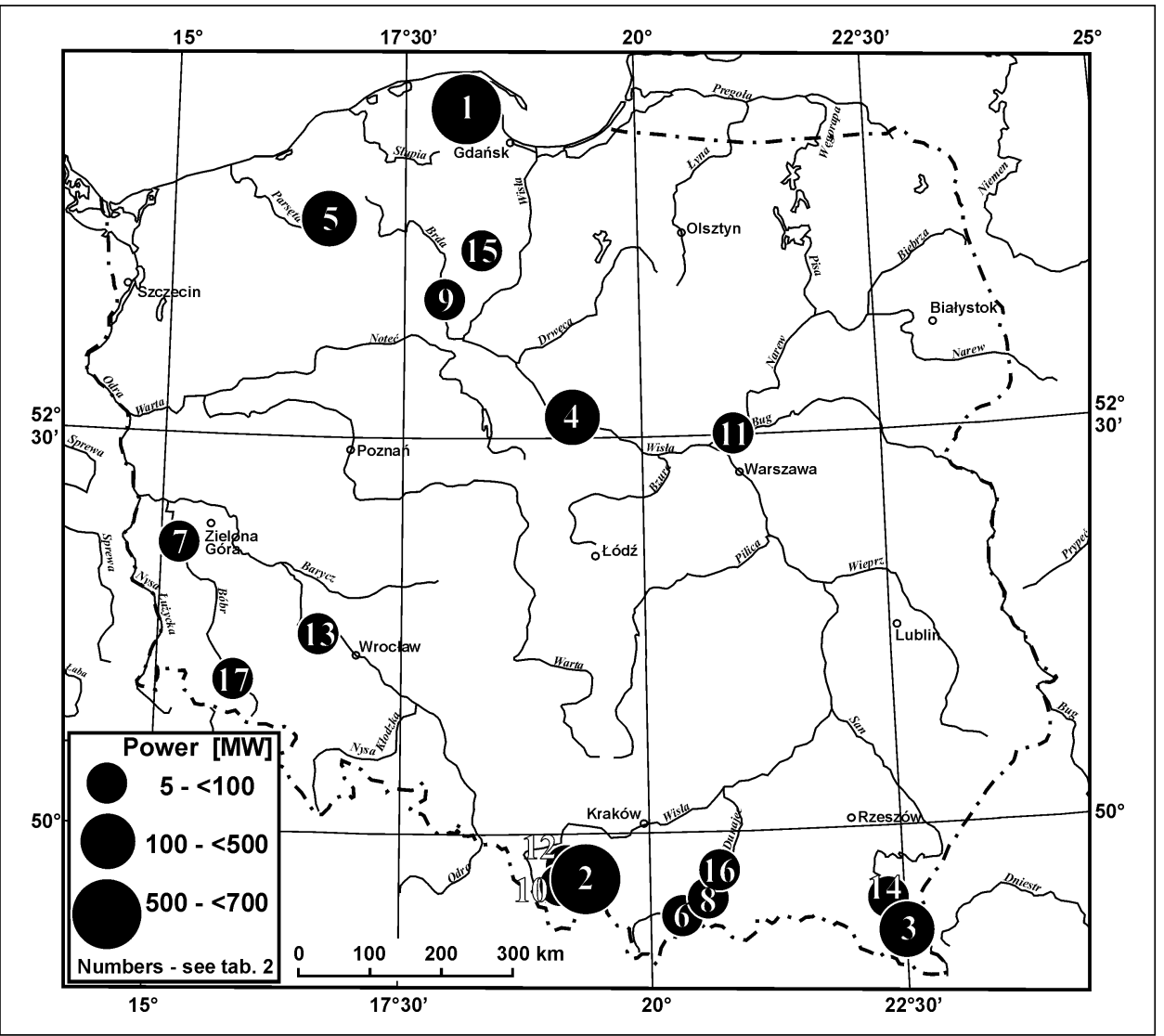

Fig. 2. Location of hydro-electric power stations in Poland.

S.A.” was founded. The company became the owner of the production assets, including four peak-flow pumped-storage hydro-electric power stations: Żarnowiec, Porabka and Żar, Tresna; Dychów; Solina and Myszkowice; as well as 16 small hydro power stations. As can be read in the information supplied by the company: "The exploitation of the reservoirs of various types by the Company makes it possible to store water in case of flood and of other unpredictable events. This has an advantageous influence on the environment, protecting against natural disasters and similar unusual events... Moreover, Peak-flow Pumped-storage Water Power Stations S.A. participate in the maintenance of stages, co-operating with water management industry financed from the state budget. The participation of the Company influences to a considerable extent the exploitation and maintenance of stages on a satisfactory technical level... Ecological actions of this type minimalise the influence of water power stations on the environment, and in some cases they even enrich it." 
Hydro power stations in Poland (large and medium) in the order of power

\begin{tabular}{|c|l|l|c|c|}
\hline Nr & \multicolumn{1}{|c|}{ Name } & \multicolumn{1}{c|}{ River } & Year & Power (in MW) \\
\hline 1 & Żarnowiec & Lake Żarnowieckie & 1982 & 680.0 \\
\hline 2 & Porąbka-Żar & Soła & 1797 & 500.0 \\
\hline 3 & $\begin{array}{l}\text { Solina (before modernisation) } \\
\text { Solina (after modernisation) }\end{array}$ & Soła & 1968 & $\begin{array}{c}136.0 \\
2003\end{array}$ \\
\hline 4 & Włocławek & Wisła & 1970 & 162.0 \\
\hline 5 & Żydowo & $\begin{array}{l}\text { Lake Kamienna and } \\
\text { Lake Kwieckie }\end{array}$ & 1971 & 151.0 \\
\hline 6 & $\begin{array}{l}\text { Czorsztyn-Niedzica } \\
\text { Sromowce Wyżne }\end{array}$ & Dunajec & 1997 & 92.1 \\
\hline 7 & Dychów & Bóbr & 1936 & 79.5 \\
\hline 8 & Rożnów & Dunajec & 1941 & 50.0 \\
\hline 9 & Koronowo & Brda & 1961 & 26.0 \\
\hline 10 & Tresna & Soła & 1967 & 21.0 \\
\hline 11 & Dębe & Narew & 1963 & 20.0 \\
\hline 12 & Porąbka & Soła & 1953 & 12.6 \\
\hline 13 & Brzeg Dolny / Wały Ślaskie & Odra & 1958 & 9.8 \\
\hline 14 & Myczkowce & San & 1962 & 8.3 \\
\hline 15 & Żur & Wda (Czarna Woda) & 1929 & 8.0 \\
\hline 16 & Czchów & Dunajec & 1951 & 8.0 \\
\hline 17 & Pilchowice & Bóbr & 1912 & 7.5 \\
\hline 18 & Bielkowo & Radunia & 1925 & 7.2 \\
\hline
\end{tabular}

$$
* * *
$$

Finally, one should state that nowadays water power stations in Poland supply the total of over $2200 \mathrm{MW}$ of electric power, which is barely a little over $6.5 \%$ of power installed in our power system. This estimate of the share of the water power, commonly given in statistics, is highly inappropriate. Water power is namely a renewable energy source, as opposed to the classical energy sources (coal, gas, oil). It is capable of meeting the peak demands of the consumers, and energy obtained in peak-flow pumped-storage water power stations can, during the periods of smaller power needs, be stored in a way.

Further possibilities of the utilisation of water power in Poland by the power industry can be found above all in the utilisation of the flow of the lower Vistula, once it is managed from the hydrotechnical point of view, as a European waterway of international importance. Other, much more modest possibilities are building new larger retention reservoirs and modernising some existing water power stations, in particular transforming them into peak-flow pumped-storage water power stations (e.g., power stations in 
Solina, Porabka, Dychów). This requires working out a strategy of the development of the water management in Poland.

\section{REFERENCES}

Bajkiewicz-Grabowska E., Mikulski Z., 1999, Hydrologia ogólna [General Hydrology; in Polish], 3rd edition. Wydawnictwo Naukowe PWN, Warszawa.

Energia odnawialna - Polska. Zasoby i wykorzystanie 2001; mapa 1:1.2 mln [Renewable Energy - Poland. Resources and Utilisation 2001; map 1:1.2 million; in Polish]. Wydawnictwo Gea, Warszawa.

Eckholt M., Löber U., Tonsman X. (eds), 1985, Geschichte der Wasserkraftsnutzung, Selbstverlag des Landesmuseum Koblenz, Koblenz.

Herbich H., 1938, Zagadnienie sit wodnych [The Issue of Hydro Power; in Polish], Warszawa.

J os t H., 1992, Energetyka [Power Engineering; in Polish], in: $Z$ dziejów techniki $w$ dawnej Polsce [History of Technology in Old Poland; in Polish], ed. by B. Orłowski. Wydawnictwo IHNOiT, Warszawa.

Kubiatowski J., 1990, Polski Komitet Energetyczny [Polish Power Industry Committee; in Polish], in: Stownik polskich towarzystw naukowych [Dictionary of Polish Scientific Societies; in Polish], vol. II, part I. Ossolineum, Wrocław.

Mikulski Z., 1995, Gospodarka wodna [Water Management; in Polish], in: Historia nauki polskiej. Wiek XX [History of Polish Science. 20th Century; in Polish], ed. by A. Śódka - Nauki o Ziemi [Earth Sciences; in Polish], ed. by Z. Mikulski, Instytut Historii Nauki PAN, Warszawa.

Mikulski Z., 1998, Gospodarka wodna [Water Management; in Polish], Wydawnictwo Naukowe PWN, Warszawa.

Mikulski Z., 2002, The Increase in Reservoir Retention in Poland, Miscellanea Geographica, vol. 10, Uniwersytet Warszawski, Warszawa.

Mikulski Z., 2003, Miejsce Gabriela Narutowicza w polskiej kulturze technicznej [The Place of Gabriel Narutowicz in Poland's Technological Culture; in Polish], Wiadomości IMGW, vol. XXVI (XLVII), 1.

Rybczyński M., 1936, Sity wodne w Polsce [Water Power in Poland; in Polish], Polski Komitet Energetyczny, Warszawa.

S poz J. (ed.), 1998, 100 lat energetyki wodnej na ziemiach polskich [100 Years of Hydro Power Engineering in Poland; in Polish], Towarzystwo Elektrowni Wodnych, Warszawa.

Zarys planu perspektywicznego gospodarki wodnej $w$ Polsce [An Outline of the Long-term Water Management Plan for Poland; in Polish], vol. II, 1959, Komitet Gospodarki Wodnej PAN. PWN, Warszawa.

English translation: Matgorzata Mikulska 